\title{
The Effects of Coordination and Movement Education on Pre School Children's Basic Motor Skills Improvement
}

\author{
Mustafa Altinkök \\ Department of Physical Education and Sports, Akdeniz University, Turkey
}

Copyright $\bigcirc 2016$ by authors, all rights reserved. Authors agree that this article remains permanently open access under the terms of the Creative Commons Attribution License 4.0 International License

\begin{abstract}
This research was conducted for the purpose of analyzing the effect of the movement education program through a 12-week-coordination on the development of basic motor movements of pre-school children. A total of 78 students of pre-school period, 38 of whom were in the experimental group and 40 of whom were in the control group, were incorporated into the study in line with their own consent after their families had also been informed. During the research period, the experimental research model with a "pre-test - post-test control group" was used. In order to determine the effect of the movement education program through coordination on children; agility, swiftness, standing long jump tests as well as the tests concerned with throwing a tennis ball, sprinting (speed running), flexibility, vertical jump, and running coordination tests and flamingo balance motor performance tests were performed. In the analysis of the data, the "independent t" package program was used to find out the difference between the experimental and control groups, whereas to find out the experimental and control intra-group differences, the "paired samples t" statistical package program was used. As for the statistical results between the pre-test values of the groups and the pre- and post-test values of the control group, no significant difference was found in any of the variables, Whereas, between the post-test values of the groups and the pre-and post-test average values of the experimental group, significant differences at different levels were found in favour of the experimental group and the post-test during the motor performance tests. Consequently; it follows that the movement education program through coordination, which has been planned and prepared for long-term practices and in which children's activities during practices are enhanced, will enable pre-school children to develop their basic motor movements as well as bringing them to the point at which they will be available for the next upper educational degree as having ensured their psycho-motor development phases.
\end{abstract}

Keywords Movement Education, Basic Motor Movements, Coordination and Teaching

\section{Introduction}

The effects of the advancements and developments in science and technology and in educational and social sciences, which are among the current study fields in recent years, are also reflected on the fields of sports sciences and movement education. The main view on the movement education, along with the integration of recent developments into the fields of sports sciences and movement education, is focused on the fact that it is of great importance to enhance children's activeness in participating in various activities to provide an effective and efficient education through the functionality of the educational methods used in the learning-teaching process.

Coordinative properties are influential and important in teaching the sports skills, developing the relevant skills, and sustaining quality. In addition, it is considered that they will facilitate the learning cascading and formation of the complex movements, and support the adaptation to the movements in different conditions in a fast manner, and make it easier to exhibit an economic and soft flow of movement. The movement education throughout the period when children actively take part in activities is thought to positively affect their basic movements, physical body awareness, motor compatibility (strength/power, coordination, speed, swiftness) and physical compatibility (flexibility, strength, endurance) as well as the increase in their socialization levels $[1,2,3]$. In the pre-school stage, one of the efficient teaching methods is the Coordinated-Movement Teaching, which is used to develop the big and small muscles in the psychomotor area in game and activity classes. It is reported that, with the increasing complexity of the movement, the coordination level that is needed for the performance is also important, and the coordinative skills are classified as the motor learning, motor guiding, motor adaptation and changing skills [4, 5]. Pedagogically, however, it can be defined as follows: "Co-ordination stands for the overall abilities concerned with showing reactions to challenging and complicated movements or skills, exhibiting them in the form of behaviour, and being capable of learning or teaching those 
movements and skills within a very short period of time by quickly adapting the somatic configuration / constitution in accordance with its purpose and circumstances in different environments". The configuration/constitution rate of the brain development and synaptic connections of pre-school children is known to be experienced at its most intense and rapid pace. It is reported that coordination practices prove to be more efficient at early ages, and that the processes of processing concepts and information become weakened along with the increasing age $[6,7,8,9,10]$.

Generally, coordination exercises are examined in three classes $[1,6,11,31,32]$.

1. Exercises intended for the perfection of basic movement forms, and for the enrichment of motor experiences (they correct all the general movement forms like Running, Jumping, Throwing and Climbing).

2. Exercises intended to clarify and perfect the coordination skill,

a- Non-disjunction exercises (Shooting the target with various tools are limited with certain time, bouncing the ball)

b- Direction finding exercises (Jumping to the target, Bouncing the ball in the track, Jump-racing and throwing a rolling ball)

c- Balance exercises (Jumping, Gymnastics / throwing / holding a ball in the balancing beam and clashing the ball, swimming/running etc.)

d- Reaction exercises (Start exercises done from different start points and from various signals)

e- Rhythm exercises (running or ball games according to predefined rhythm, The movements of the opponent must be followed)

3. Special coordination exercises that are intended to perfect the conditional skills. They are intended to perfect the coordination skills. They are applied for advanced level sportsmen.

The brain development of the children during this period paves a powerful way for their cognitive, linguistic, motor, social and emotional development, and particularly during this period, as in puberty, the child grows up quite rapidly and his/her developmental areas mature surprisingly fast, as well Thus, it is thought that this period of the individual is the most suitable time to reinforce the characteristics of motor adaptation, coordination and adaptation more harmoniously and permanently, which is also thought to be associated with the child's power of exploration, his/her capacity of learning as well as the learning rate, the supportive attitudes of his/her environment and the learning-teaching facilities provided for him/her [11, 32, 33]. Children's joining activities that are suitable for their individual properties means starting constructing knowledge and skills. It may not be possible that each child participating in the activity performs or imagines it in accordance with its requirements at the same level.
However, the teacher must, at this level, ensure a rich activity medium in which everybody can take part at a medium difficulty level. For this purpose, first of all, it is compulsory that the activity process is followed, activities that are proper for every level are included, and the acquisitions are determined. In addition, the teacher must be able to act as a good guide in the learning-teaching process, as a navigator, a leader, and as the applier of the feedbacks, corrections and reinforcements at the right time and at the right place.

In 2004, The U.S. Department of Health and Human Services issued Physical activity for children: A statement of guidelines for children ages 5-12. Reston. These guidelines include the following recommendations for Preschoolers children [12]:

Guideline 1: Preschoolers should accumulate at least 60 minutes of structured physical activity each day.

Guideline 2: Preschoolers should engage in at least 60 minutes -- and up to several hours -- of unstructured physical activity each day, and should not be sedentary for more than 60 minutes at a time, except when sleeping.

Guideline 3: Preschoolers should be encouraged to develop competence in fundamental motor skills that will serve as the building blocks for future motor skillfulness and physical activity.

Guideline 4: Preschoolers should have access to indoor and outdoor areas that meet or exceed recommended safety standards for performing large-muscle activities.

Guideline 5: Caregivers and parents in charge of preschoolers' health and well-being are responsible for understanding the importance of physical activity and for promoting movement skills by providing opportunities for structured and unstructured physical activity.

In the research, it was aimed that the effect of movement education method through coordination on the basic motor movements of pre-school children be put forward in order to facilitate skill acquisition and to prepare the children for becoming versatile for the next upper educational level by means of developing their larger and smaller muscle groups of the psycho-motor field during the lessons involving movement and game activities included in the pre-school educational program. In addition, it is considered that the study will contribute greatly to the revision and organizing of the preschool movement education plan. In line with this objective, the answers to the following questions were tried to be sought: 1. Can the movement education method through coordination be applied to pre-school children?

2. Is the movement education method through coordination effective on the development of the basic motor movements of children?

3. Is it possible to ensure children's activeness/activity by using the movement education method through coordination?

4. Is there any difference between the experimental group in which the movement education method through 
coordination is practised and the control group in which this method is not practised in terms of the development of basic motor movements?

\section{Method}

In this research, the experimental model with the "pretest-posttest control group" was used, and the relationships between the dependent variable and a series of independent variables were analyzed. The effect of the movement education method through coordination- which was determined as the independent variable and the effect of which was to be investigated - on the development of basic motor movements determined as the dependent variable was investigated.

The Study Group consisted of 78 students, who were registered in preschool educational institutions, and who did not have attendance issues, which is in the same direction of the purpose of the study. 40 students ( 20 girls - 20 boys) constituted the Control Group; and 38 students (19 girls - 19 boys) constituted the Study Group. The students were determined by paying attention of the number of the boys and girls being equal and by using the random selection technique. All of the parents of the children were informed about the study, and the parent permissions were received before the study started.

The subjects selected for the research were identified through a random selection in line with the objective of the research, and these subjects comprised a total of 78 students, 38 of whom belonged to the experimental group and 40 of whom belonged to the control group in which there were students enrolled in the pre-school educational institutes as well as those without any attendance problems. All the parents of the children involved were informed about the study, after which the study was initiated in the wake of receiving the necessary parent permissions.

\subsection{Data Collection}

Coordination racetracks (the skill or skills that are intended to be developed are placed in stations one after the other, and children are ensured to develop their skills in this track as a whole unit of activities) were designed and practised in accordance with the characteristics of the trainings and along with the active participation of the children in activity classes, sports halls and school yard, as well.

The measurements/assessments were performed by three people consisting of a researcher, a measurement assistant and an interviewer who noted down the scores obtained from the tests into the forms. The data collection was performed at 4 stages. These stages are as follows:

\subsubsection{Preliminary Study}

The activities involving movement education through Coordination, which were practised during the research period and the effect of which were investigated, were prepared by the researcher by taking the expert views into consideration, as well. Prior to the commencement of 12-week-activities involving movement education through Coordination, a preliminary study was performed for the purpose of initiating the pre-tests on all the subjects at the same level, applying the test instructions, arranging the measurement platforms, calculating the mean duration-per-test as well as testing the measurement tools and providing group homogeneity. The formation of the Study Group and the Control Group was realized in this stage by paying attention to the number of the boys and girls being the same. The formation of the Study Group and the Control Group was realized in this stage by paying attention to the number of the boys and girls being the same.

\subsubsection{Application of Pre-Tests}

The pre-tests, in accordance with the pre-study results, were applied by being separated into 5 business days by being arranged in the way that the tests of both groups would be followed by one another. During the pre-test practices, all the students were made to go through Basic Motor Movement tests, such as Agility, Swiftness, Standing Long Jump, Tennis Ball Throwing, Speed Race/Sprinting, Flexibility, Vertical Jump/Leap, Running Coordination and Static Balance motor performance tests, and hence, the measurements were completed.

On the $\mathbf{1}^{\text {st }}$ day, "agility" and "standing long jump" tests,

On the $2^{\text {nd }}$ day, "swiftness" and "tennis ball throwing" tests,

On the $3^{\text {rd }}$ day, "flexibility" and "sprinting (speed race)" tests,

On the $4^{\text {th }}$ day, "vertical leap" and "running coordination" tests, and

On the $5^{\text {th }}$ day, "static balance" tests were performed, respectively.

In the course of the practices, the movements were demonstrated to the children once, the attention was drawn to the characteristics of the movements involved, the instructions on test tools were explained, and the children were provided with feedback, corrections/re-adjustments and reinforcers.

\subsubsection{Application of Physical Education (PE) Program}

During the study; the experimental group, after the pre-test measurements, was subjected to the activities of Movement Education through Coordination, which has a number of variations and in which there are activities for developing Basic Motor Movements, for a total of 12 weeks in the form of two days a week and two course hours a day. Whereas, the control group was regularly subjected to the activities involving games and movement education included in their program for 12 weeks.

\subsubsection{Application of Post-Tests}

During the post-tests, motor performance test tools 
applied in the pre-tests were used for pre-school children in order to put forward the effectiveness of the method of Movement Education through Coordination that is used as an educational method during the courses involving movement and games activities and also to measure whether Basic Motor Movements developed or not. Also in the post-tests was the test procedures used in the same way as in pre-tests.

\subsection{Data Analysis}

During the research, the statistical package program was used for obtaining the results. The "independent $t$ " test was used to find out the difference between the experimental and control groups, whereas to find out the experimental and control intra-group differences, the "paired samples $t$ " statistical tests were used. The statistical significance levels varied according to Motor Performance tests.

\section{Findings}

In this section, the data obtained from the statistical tests that were performed were analyzed, and the findings were included in this section in line with the development of motor movements followed up during the process of practice.

As can be seen in Table 1, as the result of the 'independent t" test performed to determine whether or not there was any significant difference among the averages of Pre-test agility, swiftness, long jump, tennis ball throwing, sprinting, flexibility, vertical leap, running coordination and static balance motor performance test values pertaining to the experimental and control groups, the differences between group averages were found to be statistically insignificant $(\mathrm{p}>0,05)$.

Table 1. Pre-test agility, swiftness, long jump, tennis ball throwing, sprinting, flexibility, vertical leap, running coordination and static balance motor performance test values pertaining to the experimental and control groups.

\begin{tabular}{|c|c|c|c|c|c|c|}
\hline \multirow{2}{*}{ Test } & \multirow{2}{*}{ Group } & \multirow{2}{*}{$\mathrm{N}$} & \multirow{2}{*}{ Mean \pm SD } & \multicolumn{3}{|c|}{$\mathrm{T}$ test } \\
\hline & & & & $\mathrm{T}$ & sd & $\mathrm{P}$ \\
\hline \multirow{2}{*}{ Agility } & Experimental & 38 & $6,93 \pm, 70$ & \multirow{2}{*}{$-1,03$} & \multirow{2}{*}{76} & \multirow{2}{*}{, 347} \\
\hline & Control & 40 & $7,08 \pm, 65$ & & & \\
\hline \multirow{2}{*}{ Swiftness } & Experimental & 38 & $6,88 \pm, 68$ & \multirow{2}{*}{$-1,14$} & \multirow{2}{*}{76} & \multirow{2}{*}{, 336} \\
\hline & Control & 40 & $6,65 \pm, 64$ & & & \\
\hline \multirow{2}{*}{ Long Jump } & Experimental & 38 & $83,24 \pm 13,05$ & \multirow{2}{*}{$-1,31$} & \multirow{2}{*}{76} & \multirow{2}{*}{,314 } \\
\hline & Control & 40 & $87,35 \pm 14,46$ & & & \\
\hline \multirow{2}{*}{ Tennis Ball Throwing } & Experimental & 38 & $8,42 \pm 2,40$ & \multirow{2}{*}{$-1,38$} & \multirow{2}{*}{76} & \multirow{2}{*}{, 170} \\
\hline & Control & 40 & $9,31 \pm 3,19$ & & & \\
\hline \multirow{2}{*}{ Sprinting } & Experimental & 38 & $7,79 \pm, 73$ & \multirow{2}{*}{, 31} & \multirow{2}{*}{76} & \multirow{2}{*}{, 881} \\
\hline & Control & 40 & $7,74 \pm, 82$ & & & \\
\hline \multirow{2}{*}{ Flexibility } & Experimental & 38 & $14,70 \pm 2,90$ & \multirow{2}{*}{2,30} & \multirow{2}{*}{76} & \multirow{2}{*}{,645 } \\
\hline & Control & 40 & $13,17 \pm 2,95$ & & & \\
\hline \multirow{2}{*}{ Vertical Leap } & Experimental & 38 & $15,03 \pm 2,84$ & \multirow{2}{*}{$-2,46$} & \multirow{2}{*}{76} & \multirow{2}{*}{,948 } \\
\hline & Control & 40 & $16,65 \pm 2,97$ & & & \\
\hline \multirow{2}{*}{ Running Coordination } & Experimental & 38 & $5,53 \pm, 81$ & \multirow{2}{*}{$\begin{array}{l}-2,78 \\
-2,79\end{array}$} & \multirow{2}{*}{76} & \\
\hline & Control & 40 & $6,08 \pm, 93$ & & & , 425 \\
\hline & Experimental & 38 & $25,99 \pm 15,53$ & & & \\
\hline Static Batance (FTamming) & Control & 40 & $34,97 \pm 15,31$ & $-2,3 /$ & 10 &, $5 \angle 0$ \\
\hline
\end{tabular}


Table 2. Pre- and Post-test agility, swiftness, long jump, tennis ball throwing, sprinting, flexibility, vertical leap, running coordination and static balance motor performance test values pertaining to the control group.

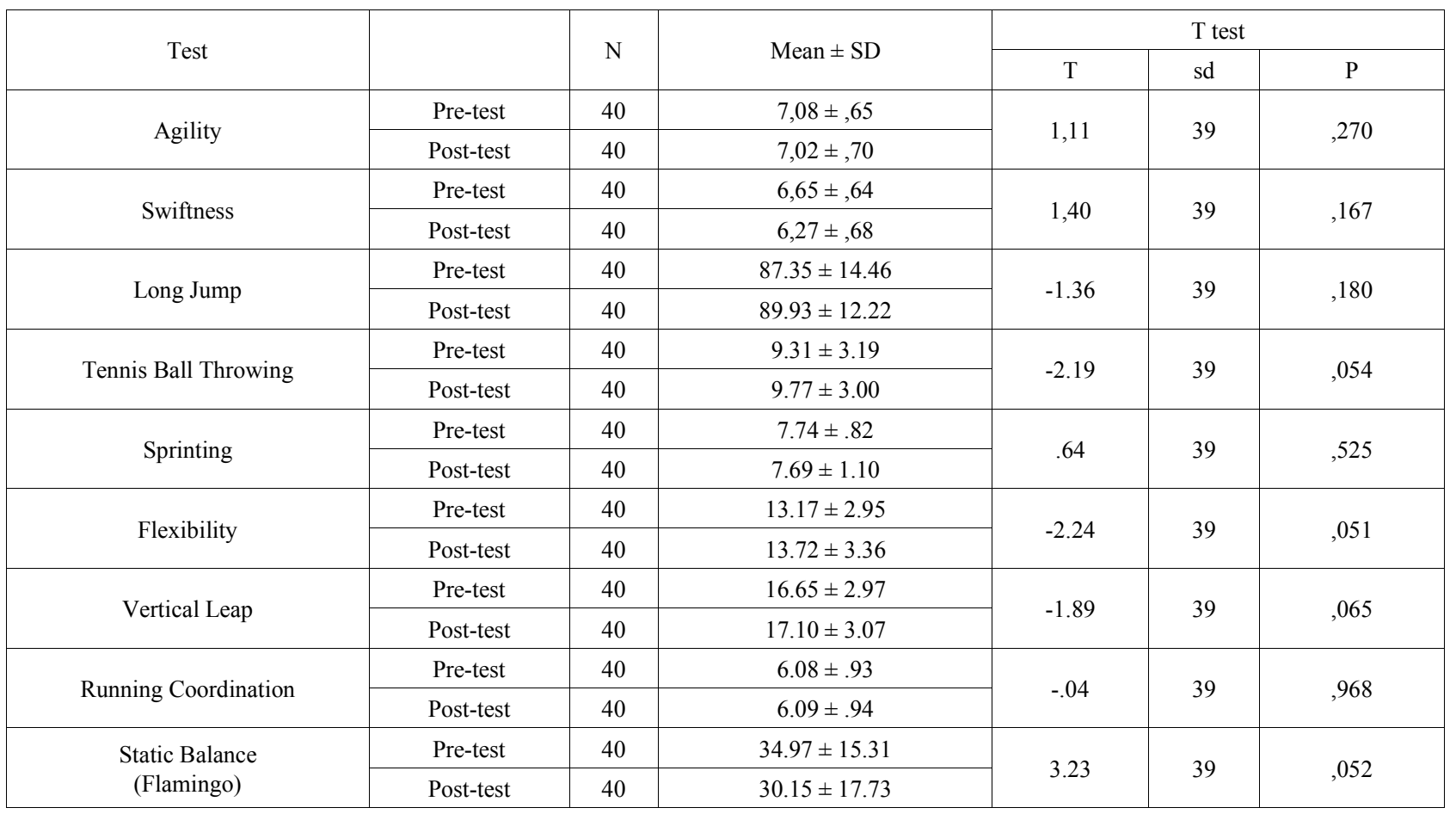

As can be seen in Table 2, as the result of the "paired samples t" test performed to determine whether or not there was any significant difference among the averages of Pre- and Post-test agility, swiftness, long jump, tennis ball throwing, sprinting, flexibility, vertical leap, running coordination and static balance values pertaining to the control group, the differences between group averages were found to be statistically insignificant, the difference among the group averages was found to be insignificant $(\mathrm{p}>0,05)$.

Table 3. Pre- and Post-test agility, swiftness, long jump, tennis ball throwing, sprinting, flexibility, vertical leap, running coordination and static balance motor performance test values pertaining to the experimental group.

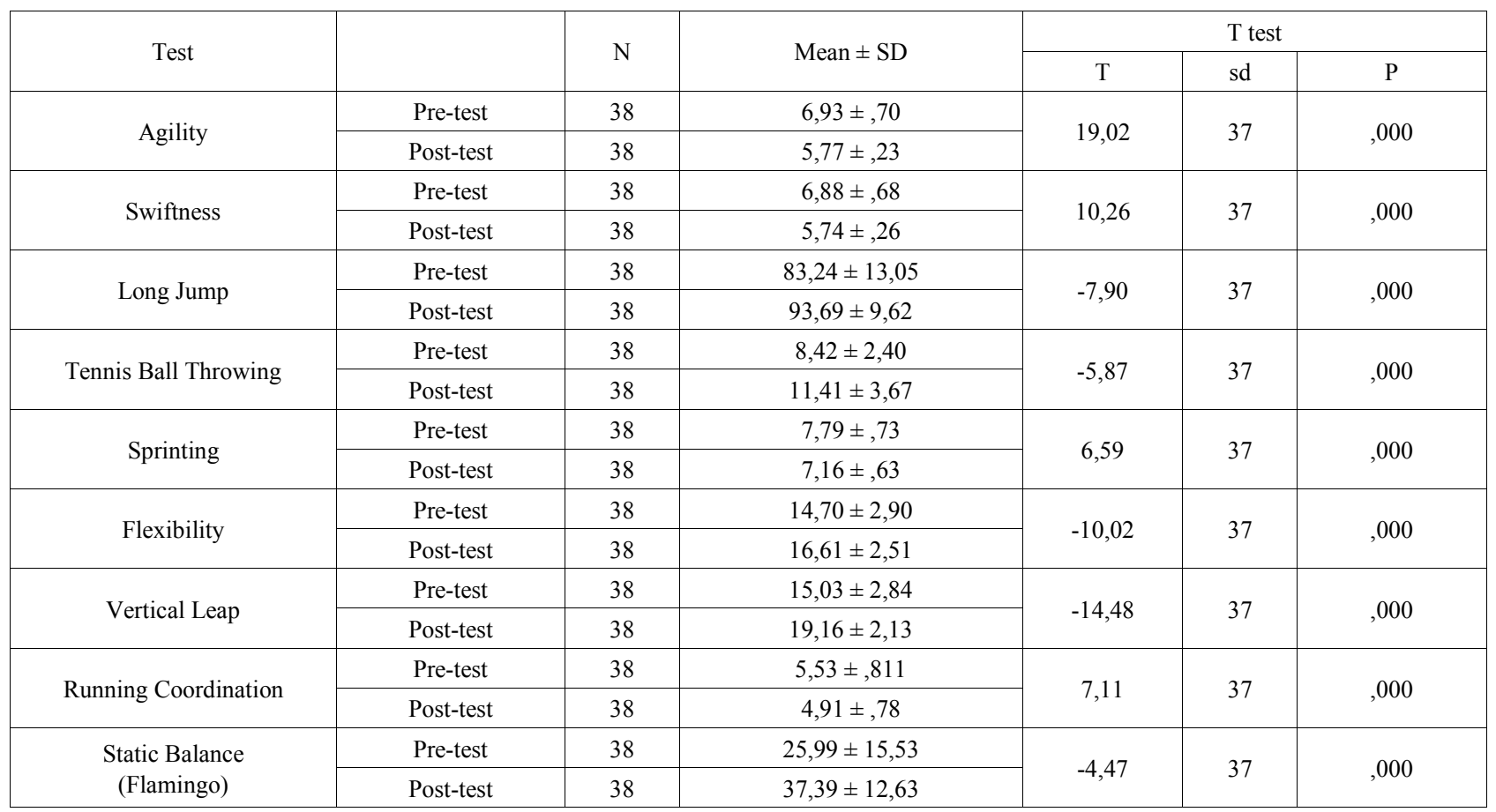


As can be seen in Table 3, as the result of the "paired samples $t$ " test performed to determine whether or not there was any significant difference among the averages of Preand Post-test agility, swiftness, long jump, tennis ball throwing, sprinting, flexibility, vertical leap, running coordination and static balance values pertaining to the experimental group, the difference among the group averages were found to be statistically insignificant, the difference among the group averages was found to be statistically significant at the level of ,01 $(p<0,01)$. The differences in question proved to be in favour of the post-tests. This difference that proved to be in favour of the post-tests is thought to be due to the effectiveness of the activities involving Movement education through Coordination that was practised.

As can be seen in Table 4, as the result of the "independent t" test performed to determine whether or not there was any significant difference among the averages of Post-test agility, swiftness, long jump, tennis ball throwing, sprinting, flexibility, vertical leap, running coordination and static balance values pertaining to the experimental and control groups, there were statistically significant differences in the averages of agility, swiftness and vertical leap test values at the level of, $01(p<0,01)$, whereas in the averages of Long Jump, Tennis ball throwing, Sprinting, Flexibility, Running Coordination and Static Balance test values, statistically significant differences at, 05 level were found $(p<0,05)$. The differences in question proved to be in favour of the experimental group. This difference that proved to be in favour of the experimental group is thought to be due to the effectiveness of the activities involving Movement education through Coordination that was practised.

Table 4. Post-test agility, swiftness, long jump, tennis ball throwing, sprinting, flexibility, vertical leap, running coordination and static balance motor performance test values pertaining to the experimental and control groups.

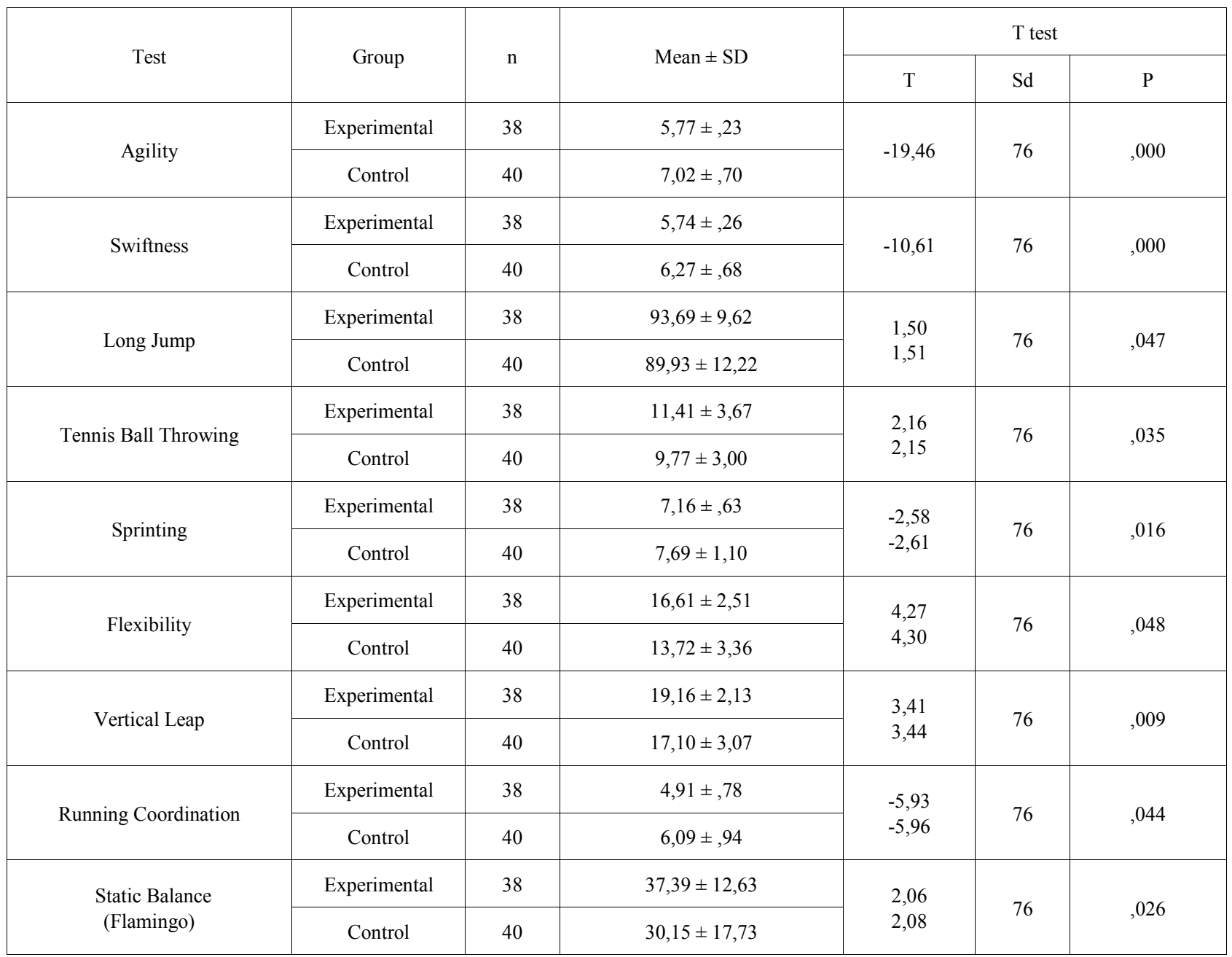




\section{Discussion and Results}

During the research; the movement education program through coordination was applied to the experimental group during the lessons involving movement and game activities included in the pre-school program for 12 weeks in the form of 2 days and 4 course hours a week. The control group, however, was made to perform the activities required during the lesson hours involving movement and games activities within the same time-frame, and they were not incorporated into the movement education program through co-ordination. In this research, the development of basic motor movements of the children in the experimental group in which the method of Movement Education through Coordination was practised progressed far better than the basic motor movements of those in the control group, and the difference between them was found to be significant in favour of the experimental group. Other study results that seem to support this research are as follows:

As the result of the studies conducted by Rutledge (1993), Zülkadirlioğlu (1995), Aytekin (2001), Şen (2004), Kerkez (2004), Dursun (2004), Ballı (2006), Altınkök (2006), Kerkez (2006), Özdenek (2007), Kırıcı (2008), Karagöz (2009), Öztürk (2009), Çelebi (2010), Ulutaş (2011), Boz (2011), Boz \& Aytar (2012), Şahin et al. (2012), Fuchslocher et al. (2013), Yarımkaya \& Ulucan (2015), Şenturk et al. (2015) and Altınkök (2015), it is seen that in the development of motor skills, physical development and compatibility and in the development of the components of different sports branches, the absolute development values, when compared with the other children, proved to be higher and more significant in the children on whom different movement education models were practised in a planned and long-term fashion. On the other hand, Çağlak (1999), apart from the conventional methods of education, compared the education on the concept of energy with the education of physical activities in the children aged between 5-6. As a result, it was put forward that as the education on the concept of energy was concerned, the physical education activities in the children aged 5-6 were more effective than the conventional education $[13,14,15,16,17$, $18,19,20,21,22]$. Chatrath (2002), in his study in which the physical fitnesses/adaptabilities of the children living in the cities of the USA were analyzed, emphasized the fact that the children whose activities were supposed to be kept at high levels but were ignored had suffered from cardiovascular problems during their adulthood; thus, he came to the conclusion that it was of great importance to pay attention to the activity programs performed during childhood. It is reported that as for the children participating in sports activities during the pre-school period, there will be an increase to be observed in their physical activities and development as well as their social skills by maintaining a collaboration with the specialists in this field, as well [24]. The preference of recreative activities for a healthy and active life-style reduces obesity and minimizes smoking habits by increasing the mental health more and more and becomes efficient in raising healthy and conscious individuals. It was put forward by a number of researches that active life-style and participation in recreative activities during childhood lead to an active adulthood at later ages $[25,26]$. It is considered that determining the time and place of recreative activities to be performed and organizing them in the way that they will be beneficial for children are of great importance, and it is thought that such activities need to be supported by the State and private institutions, as well [27, 28].

In Arıkan's (2002) study, which was conducted for the purpose of evaluating the physical activity programs performed in the pre-school educational institutions in Ankara, it was determined that physical activities were included within the program, and that the managers of the involved institution had played a role in specifying the curriculums/programs, while the graduates of the Department of Pediatric Development in universities had played a role in the implementation of these programs; yet, it was also ascertained that the graduates of the Department of Physical Education had participated less in the practices involving these activities. In the course of performing movement education, on the other hand, it was stated that balls were used at most as materials of training, whereas materials like ropes, hoops and cushions were hardly used [18]. Korkmaz \& Kuter (2002), however, came to the conclusion that in pre-school educational institutions, there was the need for instructors who were experienced and trained in the field of movement education, and that the activities involving movement education had to be implemented by the instructors experienced in this field. In the study conducted by Korkmaz \& Erol (2004), the teachers/instructors in Bulgaria and in Turkey were observed to provide time for leisure time activities as well as taking part in those activities; yet, with respect to the development of rough and fine motor skills in the psychomotor field, the instructors in Turkey were observed to provide very little time for balance and coordination activities when compared with those in Bulgaria; moreover, they were determined to have spared time for running and jumping skills as well as for fine motor skills instead. In line with this, it is understood that the instructors/teachers trained and educated in Turkey do not promote the coordinative faculties as sufficiently as possible, nor as much as it should be $[29,30]$.

In conclusion; These results seem to support the fact that the field experts in these practices are not proficient in participating in the activities, and that the movement education programs provided for children consist of extremely insufficient and single-level practices in terms of coordination skills, and that the activities regarding movement education must be implemented only after the experts involved in this field or those experienced in this field have provided the necessary in-service training for the instructors of pre-school movement education. When the studies regarding movement and physical activity for healthy 
growth in pre-school children and the international literature are taken into consideration, it is thought that guidelines on physical activity, movement and games must be very urgently prepared for families, instructors and institutions during the pre-school period, and that convenient and equal conditions must also be provided in terms of physical activity and movement in pre-school institutions $[18,22]$. The development of basic motor movements of the children in the experimental group in which the movement education method through coordination was practised was observed to have shown a much better progress than the basic motor movements of those in the control group, and the difference between them was found to be in favour of the experimental group. Along with the results of the research, it follows that apart from clearly mentioning the importance of educational movement practices so as to develop the larger and smaller muscle groups of the psycho-motor field, the effect of the methods used in education is also great, and the movement education method through coordination has an impact on maintaining and supporting the development of basic motor movements and body coordinations of children as well as supporting the other delicate and indelicate motor muscle groups. Researches as to what methods that are more effective and efficient for children could the pre-school movement education program be provided through as well as determining the problems experienced in this field are advised to be performed for prospective studies.

\section{REFERENCES}

[1] Schilling, F. \& Kiphard, E.S. (1974). Körperkoordinations test für Kinder (KTK). Beltz Verlag Weinheim.

[2] Kosel, A. (1994). Schulung der bewegungskoordination. Beratungsstelle für Schadenverhütung des HUKVerbandes Köln (Hrsg.). Schorndorf .

[3] Milli Eğitim Bakanlığı. (2013). Milli eğitim bakanlığı okul öncesi eğitimi programı. Ankara.

[4] Meinel, K. \& Schnabel, G. (1987). BewegungslehreSportmotorik. Abriss einer Theorie der sportlichen Motorik unter pädagogischem Aspekt. Berlin: Sportverlag

[5] Thies, K.M. \& Travers, J.F. (2006). Handbook of human development for health care professionals. ISBN: 0763736147 9780763736149, Sudbury, Mass.: Jones and Bartlett Publishers, Canada.

[6] Wellnitz, I. \& Hirtz, P. (1983). Langzeitwirkungen eines pädagogischen Experimentes zur Entwicklung koordinativer Fähigkeiten in der Unterstufe. Körpererziehung 33, 4-7.

[7] Hirtz P. (Red.) (1988). Koordinative Fähigkeiten im Schulsport . Berlin: Sportverlag

[8] Bös, K. \& Wohlmann, R. (1987). Allgemeiner sportmotorischer test für kinder (AST 6-11) zur diagnose der konditionellen und koordinativen leistungsfähigkeit. Lernhilfen für den Sportunterricht 36, 145-160.
[9] Altfeld, K. (1998). Die entwicklung der gesamt körperkoordination im grundschulalter. Diplomarbeit Köln.

[10] Vale, S., Silva, P., Santos, R., Soares-Miranda L. \& Mota, J. (2010). Compliance with physical activity guidelines in preschool children. Journal of Sports Sciences, 28(6), 603608.

[11] Schiebl, F. (Red.) (1994). Kindersportschule: Lehrplan-Allgemeine sportartübergreifende Grundlagenausb ildung für Kinder. Stuttgart: STB

[12] National Association for Sport and Physical Education. (2004). Physical activity for children: A statement of guidelines for children ages 5-12. Reston, VA: Author.

[13] Rutledge, C.D. (1993). The Level of Motor Skill Development of Preschool Children provided A Physical Education Program and Preschool Children Provided with Free Play Environments, The Dissertation for the Degree of Doctor of Education, University of Northern Colorado, Greeley, Colorado, USA.

[14] Altınkök, M. (2006). Temel motor hareketlerin geliştirilmesini içeren beden eğitimi program tasarısının 5-6 yaş çocukların temel motor hareketlerinin gelişimine etkisinin araştırılması. Yüksek Lisans Tezi. Marmara Üniversitesi, Eğitim Bilimleri Enstitüsü.

[15] Boz, M. (2011). 5-6 Yaş Grubu Çocuklara Uygulanan Temel Hareket Eğitim Programının Hareket Becerilerinin Gelișimine Etkisi. Yayımlanmamıș Doktora Tezi. Gazi Üniversitesi. Eğitim Bilimleri Enstitüsü.

[16] Boz, M. \& Aytar, G.A. (2012). Okul öncesi çocuklarında temel hareket eğitim programının hareket becerilerine etkisi. Hacettepe J. of Sport Sciences, Özel Say1 1: 51-59.

[17] Şahin, M., Saraç, H., Çoban, O. \& Coşkuner Z. (2012). Taekwondo antrenmanlarının çocukların motor gelișim düzeylerine etkisinin incelenmesi. Spor ve Performans Araştırmaları Dergisi, Cilt/Vol: 3, Sayı/No:1, 5-14.

[18] Kerkez, İ.F. (2012). Sağlıklı büyüme için okulöncesi dönemdeki çocuklarda hareket ve fiziksel aktivite. Spor Bilimleri Dergisi, Hacettepe J. of Sport Sciences, 23(1), $34-42$.

[19] Fuchslocher, J., Romann, M. \& Gulbin, J. (2013). Strategies to Support Developing Talent. Schweizerische Zeitschrift für Sportmedizin und Sporttraumatologie 61 (4), 10-14.

[20] Yarımkaya, E. \& Ulucan, H. (2015). Çocuklarda hareket eğitimi programının motor gelisim uzerine etkisi. International Journal of New Trends in Arts, Sports \&ScienceEducation, Volume 4, issue 1 ISSN: 2146-9466, $37-48$.

[21] Senturk, U., Beyleroglu, M., Guven, F., Y1lmaz, A. \& Akdenız, H. (2015). Motor skills in pre-school education and affects to 5 year old children's psychomotor development. Turkish Journal of Sport and Exercise, DOI: 10.15314/tjse.38665, Volume: 17 - Issue: 2 - Pages: 42-47

[22] Altınkök, M. (2015). Examining the effects of "activity education with coordination" on the development of balance and arm power in 6-year-old primary school children. International Online Journal of Educational Sciences, DOI: http://dx.doi.org/10.15345/iojes.2015.04.019 7 (4), 140-147 
[23] Chatratl1, R. (2002). Physical Fitness of Urban American Children, Pediatric Cardiol. Nov Dec; 23(6): 608-12.

[24] Washington, R.L. (2001). Ordanized Sports For Children and Preadolescent, Pediatrics. Jun; 107 (6): 1459-62.

[25] Gray, Ty-Am. \& Judy, O. (2003). Physical Education Rec. And Dance", Vol. 74, Iss. 6; pp 52.

[26] J1mmy, A. (2003). Participation in Extracurricular Physical in Middle Schools, Vol. 74, iss. 4, pp 10.

[27] Ballard,W. (2004). A Catalyst for Quality Physical Education. Vol 75, iss. 3; pp 40.

[28] Sandercock, G., Angus, C. \& Barton, J. (2010). Physical activity levels of children living in different built environments. Journal of Preventive Medicine, 50, 193-198.

[29] Korkmaz, H. \& Kuter, Ö. (2002). Okul Öncesi Eğitimde Görev Yapan Öğretmenlerin Beden Eğitimi Etkinliklerine Bakışı (Bursa Örneği. First Internatıonal Education
Conference. Famagusta, North Cyprus May 8-10.

[30] Korkmaz, N.H. \& Erol, S. (2004). Farklı eğitim almış ögretmenlerin okul öncesi dönemde yer alan beden eğitimi ve spor aktivitelerini uygulamaların ilişkin bir inceleme (Bursa Örneği). Journal of Physical Education and Sport Sciences, 6 (3).

[31] Hirtz, P. (2002). Koordinative Fähigkeiten - Gewandtheit motorische Kompetenz. In G. Ludwig \& B. Ludwig (Hrsg.), Koordinative Fähigkeiten - koordinative Kompetenz (S. 59-64). Kassel: Univ., FB 03 (Psychologie).

[32] Roth, K.. \& Winter, R. (1994). Entwicklung koordinativer fähigkeiten. In: Baur, J., Bös, K., Singer, R.: Motorische Entwicklung: ein Handbuch. Hofmann Schorndorf, 191-216.

[33] Mühlethaler, U. (1988). Der langfristige trainingsprozeß im handball. Von den koordinativen fähigkeiten zum bewegungslernen im handballspiel. In: Magglingen. Jugend und Sport (45), 8. 